\title{
The Equivocal Use of Power in Nietzsche's Failed Anti-Egalitarianism
}

\author{
Donovan Miyasaki \\ Associate Professor of Philosophy, Wright State University \\ 386 Millett Hall, 3640 Colonel Glenn Hwy, Dayton OH 45435, USA \\ d.miyasaki@wright.edu
}

\begin{abstract}
This paper argues that Nietzsche's anti-egalitarianism depends on equivocation between conceptions of power as quantitative superiority and qualitative feeling (das Machtgefühl) and between associated conceptions of equality as similarity (die Ähnlichkeit) and opposition or resistance (der Widerstand). Nietzsche's key arguments against equality fail when applied to the qualitative form of power, since the feeling of power does not directly correlate with quantitative ability and requires relatively equal or proportional resistance. Consequently, Nietzsche's commitment to the promotion of humanity's highest individuals does not entail the rejection of moral egalitarianism in every form and even supports a pluralistic egalitarianism that promotes equality understood not as similarity but as multiple, proportional resistances (die Veilheit, die Widerstände).
\end{abstract}

\section{Keywords}

Egalitarianism - Equality - Morality - Power - Political Theory - Resistance

Donovan Miyasaki is Associate Professor of Philosophy at Wright State University in Dayton, Ohio. He specializes in $19^{\text {th }}$ and $20^{\text {th }}$ century European philosophy and value theory, with a focus on Nietzsche, Heidegger, and critical theory. His current research focuses on the political implications of Nietzsche's critiques of free will and moral agency.

(C) KONINKLIJKE BRILL NV, LEIDEN, 2015 | DOI 10.1163/17455243-4681016 


\section{Introduction}

In this paper I argue that Nietzsche's rejection of egalitarianism depends on equivocation between distinct conceptions of power and equality. When these distinct views are disentangled, Nietzsche's arguments succeed only against a narrow sense of equality (die Gleichheit) as qualitative similarity (die Ähnlichkeit), and not against quantitative forms that promote equality not as similaritybutas multiple, proportional resistances (dieVeilheit, dieWiderstände).

I begin by distinguishing the two conceptions of power at play in Nietzsche's arguments, power as quantitative superiority of ability and as qualitative feeling of power (das Gefühl der Macht), an affective state that does not directly correlate with quantitative ability and, because based in resistance (der Widerstand), requires relative equality as its condition.

Nietzsche presents four principal arguments against egalitarianism, each concluding that equality harms the flourishing of humanity's highest individuals. First, equality directly promotes qualitative similarity (die Ähnlichkeit) at the expense of multiplicity (die Vielheit). Second, because material inequalities ground the 'pathos of distance' (the recognition of spiritual inequality), equality indirectly undermines the desire for self-development. Third, because it opposes aristocratic conditions, egalitarianism promotes a form of liberalism that removes conditions of constraint necessary to human development. Finally, equality is a less efficient means of human enhancement, which is best promoted through unequal distribution of resources to the most able individuals.

I argue that in each case Nietzsche's argument succeeds only if interpreted according to the quantitative conception of power as superiority, but fails when we also consider the qualitative conception of power as feeling. For the promotion of an individual's qualitative power is compatible with quantitative power equality. Moreover, because power is felt only in resistance, the feeling of power requires relative equality as its precondition - an alternate sense of equality construed, not as qualitative similarity, but as quantitative resistance from proportional counter-powers. I conclude that Nietzsche's commitment to the promotion of humanity's highest individuals does not entail the rejection of moral egalitarianism in every form and even supports certain forms. ${ }^{1}$

1 I should distinguish my position - in which Nietzsche's value system is compatible with or fails to successfully reject certain moral and normative claims about equality - from those who directly interpret it as a form of morality. Compare, for example, Thomas Hurka's interpretation of Nietzsche's value system as a form of moral perfectionism in 'Nietzsche: Perfectionist,' in B. Leiter and N. Sinhababu (eds.), Nietzsche and Morality (Oxford: Oxford 
The Priority of Nietzsche's Qualitative Conception of Power

Nietzsche's anti-egalitarianism is grounded in his broader moral project of the enhancement of humanity through the promotion of its highest individuals and types ${ }^{2}-$ at the expense, if necessary, of the rest of humanity. ${ }^{3}$ Nietzsche

University Press, 2007), pp. 9-31. I do not believe Nietzsche's values are intended or directly interpretable as a morality in a narrower sense - that they are presented as true or more reasonable than other values, demanding the reader's rational consent. For this reason, I will consider only whether an egalitarian morality or politics would be consistent with Nietzsche's arguments, not whether he would endorse it. For this reason, too, I will leave aside the metaethical questions of why one ought to promote egalitarianism and why one ought to promote the flourishing of humanity's highest types. Nevertheless, my conclusion that relative equality is the precondition of the feeling of power does suggest that Nietzsche has an incentive to accept some form of egalitarianism as a means to his goal of promoting humanity's highest individuals. (Note: all references to Nietzsche's work are to section numbers and use the standard abbreviations: A - The Antichrist, BGE - Beyond Good and Evil, D - Daybreak, E H - Ecce Homo, GM - On the Genealogy of Morality, Gs - The Gay Science, Gst - 'The Greek State,' HC 'Homer's Contest,' H - Human, All Too Human, TI - Twilight of the Idols, and Z - Thus Spoke Zarathustra, ws - The Wanderer and his Shadow.)

2 I consider it uncontroversial that, despite his self-proclaimed status as 'immoralist,' Nietzsche's attack on morality is limited to certain forms of morality, not all forms: 'Beyond Good and Evil' . . . At least this does not mean 'Beyond Good and Bad,' On the Genealogy of Morality, trans. M. Clark and A. Swanson (Indianapolis: Hackett, [1887] 1967), I: 17. For excellent discussions of this issue, see Brian Leiter, The Routledge Philosophy Guidebook to Nietzsche on Morality (London: Routledge, 2002), pp. 74-77, as well as Philipa Foot, 'Nietzsche's Immoralism,' Maudemarie Clark, 'Nietzsche's Immoralism and the Concept of Morality, and Frithjof Bergmann, 'Nietzsche and Analytic Ethics,' all in R. Schacht (ed), Nietzsche, Genealogy, Morality: Essays on Nietzsche's Genealogy of Morals (Berkeley: University of California Press, 1994), pp. 3-14, 15-34, and 76-94. As Raymond Geuss points out in 'Outside Ethics,' European Journal of Philosophy 11: 1 (2003), pp. 29-53, Nietzsche rejects ethical obligation on numerous grounds, including the absence of free will. However, Nietzsche may support a broader form of normativity on the level of human rather than individual agency and development: 'The problem I raise here is ... what type of human being one ought to breed, ought to will, as more valuable, more worthy of life, more certain of the future,' Twilight of the Idols and the Anti-Christ, trans. R.J. Hollingdale (New York: Vintage, [1888] 1998), 3. When he speaks of 'species-cultivating (Art-züchtend)' judgments and contrasts 'taming' and 'breeding' as forms of morality, he is suggesting that our values determine what kinds of human beings will thrive or not, and so express an effective norm about what humanity 'ought' to be (Beyond Good and Evil, trans. W. Kaufmann, New York: Vintage, [1886] 1966, 4; TI 7: 2; A 3, 57).

3 That this is Nietzsche's later view is uncontroversial. However, as John Richardson points out in Nietzsche's System (Oxford: Oxford University Press, 1996, pp. 149-50), Nietzsche does briefly entertain a very different view. In Daybreak, he considers the possibility that the highest good might require sacrificing personal power in order to 'strengthen and raise higher the 
associates the flourishing of humanity's highest types with the promotion of their power, a connection most explicit in late works like The Anti-Christ: 'What is good? - All that heightens the feeling of power, the will to power, power itself in man. What is happiness? - The feeling that power increases - that a resistance is overcome' (A 2). ${ }^{4}$

In this familiar passage, I would like to underscore three things. First, the normative claim about goodness implies that power is the measure of human value and thus of the project of enhancing humanity. ${ }^{5}$ Second, in this list of goods, the feeling of and will to power are given priority over power simply. Finally, the highest good, the feeling of power (das Gefühl der Macht), is inseparable from resistance (der Widerstand), a key Nietzschean theme that, I will argue, is conceptually inseparable from a unique kind of equality.

The contrast of power and the affect of power suggests two different ways of interpreting power, a distinction that is muddled, confused, and sometimes conflated in other places in Nietzsche's work. Indeed, we shall see that this distinction between what I will call quantitative and qualitative senses of power is notably absent from Nietzsche's arguments against equality. By equivocating between power and the feeling of power, Nietzsche can ignore aspects of qualitative power that are unhelpful to his anti-egalitarian arguments. ${ }^{6}$ Not

general feeling of human power' as a 'positive enhancement of happiness' (trans. R. J. Hollingdale, Cambridge: Cambridge University Press, 1997, 146). One implication of my argument is that Nietzsche's more favorable views of egalitarianism in middle-period works like Daybreak and Human, All Too Human may be more consistent with his later views about power and human wellbeing than he realized.

4 Leiter categorizes the promotion of happiness as characteristic of moralities Nietzsche opposes in 'Nietzsche and the Morality Critics,' Ethics, 107: 2 (1997), p. 267. However, this is true only given a narrow sense of happiness defined as absence of pain, suffering, or struggle - a sense of 'happiness' Nietzsche clearly is not using in this passage or, for example, in his effusive description of the victorious happiness characteristic of the noble form of value creation.

5 In Beyond Good and Evil 212, Nietzsche indicates that the standard of human 'enhancement' (die Vergrößerung) and the way to 'determine value and rank' is according to 'how much and how many things one could bear and take upon himself, how far one could extend his responsibility.' This criterion accurately tracks all three elements of his definition of the good in Twilight of the Idols: a greater will to power as indicated by the desire to voluntarily take on more responsibility, a greater feeling of power as experienced in the exercise of such responsibility, and a greater quantity of power as is necessary to successfully bear such a burden.

6 This equivocation is so basic that it seems to be the root of the equivocal character of other central Nietzschean concepts, for example, strength as either potency or force, mastery as self-control or domination, and happiness as intensity of feeling or satiation of need. I examine two further cases in more detail below: equality as qualitative assimilation or

JOURNAL OF MORAL PHILOSOPHY 12 (2015) 1-32 
the least of these ignored aspects is that an individual's feeling of power can be increased or decreased independently of her power quantitatively construed: there is no necessary relationship between equality of qualitative power and quantitative power. Yet it is precisely the assumption of a negative relation of equality to power that grounds Nietzsche's key arguments against egalitarianism. We are, then, justified in the suspicion that Nietzsche's equivocal use of the language of power grounds his suspicion of equality, and that his arguments against equality may not succeed when examined in light of the qualitative view.

Of course, it might be argued that the incompatibility of Nietzsche's qualitative conception of power and his arguments against egalitarianism is a concern only if, as I have claimed, Nietzsche gives priority to the qualitative view. But why should we assume the qualitative form of power is central to Nietzsche's conception of human flourishing? Returning to the passage from The Antichrist, we find that the good includes quantitative as well as qualitative forms of power: 'power itself,' not just 'will' or 'feeling.' However, this is not a list of equal, intrinsic goods; the causal relation of the three elements suggests an order of priority. The will to power causes the increase of power, and the increase of power, in turn, heightens the feeling of power. The reverse, however, does not hold: heightening the feeling of power does not necessarily increase power itself (one can mistakenly feel power, or feel relatively powerful in relation to someone less powerful), and increasing power does not necessarily increase the will to power (more power may reduce my desire for power). Consequently, this definition of the good implies the priority of feeling over quantity as end to means. Power and will to power are instrumentally good as means to the more primary end of heightened feeling. Indeed, even Nietzsche's choice of the word 'heighten' (erhöhen), a reference to level rather than quantity, with its added connotation of spiritual or emotional elevation, suggests a change in qualitative intensity rather than quantity.

The priority of qualitative power is further supported by the striking difference between Nietzsche's definitions of the good and happiness. While the good includes power and the will to power, happiness is defined solely as 'the feeling that power increases' or 'resistance is overcome. ${ }^{7}$ If the feeling of power,

quantitative resistance and the pathos of distance as awareness of either quantitative superiority or qualitative difference.

7 Notice that Nietzsche now uses 'increases' or 'grows' (wachsen) rather than the earlier term 'erhöhen,' since he is referring to the subject's feeling that there has been quantitative increase. This reinforces the priority of qualitative power by emphasizing the distinction between the subject's feeling and the fact: the condition of happiness is the subject's sense 
the volition of power, and power were equal, intrinsically valuable components of the good, they would also be equal components of human happiness. However, if, as I have suggested, power and the will to power are valuable only as means to heightened feeling, then they are not directly necessary to happiness. For power and the will to power are not intrinsic goods; they serve human happiness only as a means to the intrinsic good of heightened feelings of power.

Finally, the priority of qualitative power is well supported by its consistent reappearance in Nietzsche's discussions of power throughout his middle and late periods. This is most explicit in middle period works, in which he frequently links power and feeling in the terms 'Machtgefühl' and 'das Gefühl der Macht.' For example, in a passage from The Gay Science titled 'On the Doctrine of the Feeling of Power', Nietzsche argues that we do not truly act for specific ends such as benefitting or harming; rather, we exercise power for the sake of 'preserving our feeling of power' (GS I: 13). However, he makes the very same point in later works such as Beyond Good and Evil, where he claims that the aim of the human spirit is 'growth, in a word - or, more precisely, the feeling of growth, the feeling of increased power (Kraft)' (BGE 230). In both cases, he underlines the difference in priority; he explicitly tells us that it is preserving the feeling of power, rather than benefitting or harming, that is the aim, and that the 'feeling of increased power,' not growth itself, is the more precisely identified aim of power.

Admittedly, the language of 'Machtgefühl' is notably absent in Beyond Good and Evil. Should we conclude he has dropped the qualitative view for an entirely quantitative conception of power? Surely not, for the terms 'feeling of power' and 'power-feeling' return in the other major late works, including $\mathrm{On}$ the Genealogy of Morality, The Twilight of the Idols, and The Antichrist. ${ }^{9}$ Nietzsche even explicitly rejects a purely quantitative view of power in Beyond Good and Evil, suggesting that life seeks to exhaust its power rather than accumulate power: 'a living thing seeks above all to discharge (auslassen) its strength...self-preservation (Selbsterhaltung) is only one of the indirect and most frequent results' (BGE 13).

that there has been a quantitative increase, and not increase or growth as such. Happiness is, in other words, a heightened feeling, not an increased quantity.

8 See, for example, D 23, 112-13, 170, 184, 199, 356, and 403; Human, All Too Human, trans. R. J. Hollingdale, (Cambridge: Cambridge University Press, [1887-80] 1996), 142; and The Gay Science, trans. W. Kaufmann (New York: Vintage, [1882] 1974), I: 13.

9 GM III: 10, A 2 and 16; TI 20.

JOURNAL OF MORAL PHILOSOPHY 12 (2015) 1-32 
The temporary disappearance of the language of power-feeling in Beyond Good and Evil does indeed mark a turning point in Nietzsche's concept of power, but toward a more sophisticated conception of qualitative power, not its rejection. It is a shift not from qualitative to quantitative, but from objective property to relational property. Nietzsche preserves the qualitative aspect in the language of 'resistance' - a language that preserves the affective and relational aspect of the early qualitative view while downplaying the primacy of the subject. This is an unsurprising change in a text containing some of Nietzsche's most sustained critical arguments against the metaphysical conceptions of the self and the will. For example, it is in Beyond Good and Evil that Nietzsche identifies the experience of volition not with the act of an agent, but with contradictory feelings of tension and resistance, commanding and obeying - a feeling of relational power, but one that is not clearly attributable to a subject as affective property, a feeling that divides the subject rather than belonging to it.

This move away from subjectivity complicates the qualitative dimension of power, since the desire to heighten the 'feeling' of power may be neither a conscious desire nor a desire for conscious states of feeling, but rather a drive for the complex, relational physiological or psychological conditions of such states. However, it is also a decisive rejection of the equation of power with either simple quantity or quantitative superiority, since neither can alone produce power as a relational property of resistance. And it preserves the priority of quality by emphasizing the condition upon which the feeling of power depends: relation to resistance.

Consequently, the textual evidence for the priority of qualitative power extends beyond the explicit claims of the early work: we find extensive further support in the late work wherever Nietzsche speaks of the priority of resistance and relations of resistance as the objective condition of the feeling of power. I will examine a number of these passages in detail in the next section. For now, it suffices to note that qualitative power not only reappears in the late work as the concept of resistance, it become more frequent, constantly invoked in the late writings in a variety of ways: as resistance (der Widerstand), ${ }^{10}$ contradiction (der Widerspruch, der Gegensatz), ${ }^{11}$ opposing (widerstreben), ${ }^{12}$

10 BGE 19 and 61; GM I: 1 and III: 9; TI 8: 6 and 9: 38; A 2 and 29; Ecce Homo, trans. W. Kaufmann (New York: Vintage Books, [1888] 1967) 1: 4 and 7.

11 BGE 200; TI 5: 3; Thus Spoke Zarathusra, trans. A. D. Caro, eds. A. D. Caro and R. Pippin (Cambridge: Cambridge University Press, 2006), II: 12.

12 A 30. 
antagonism (das Gegnerschaft, die Gegner, begegnen), ${ }^{13}$ and tension (Spannung). ${ }^{14}$

\section{2 Qualitative Power and Equality as Proportional Resistance}

I will begin by drawing out in detail the distinction between quantitative and quantitative conceptions of power, then I will clarify the relation of each form of power to equality. Nietzsche's quantitative sense of power is the common, comparative sense in which an individual's power is evaluated, first, according to quantity or degree of ability and, second, according to comparative superiority of ability. For example, the evaluation that someone can play the piano well indicates both a strictly quantitative measure of ability, such as the ability to read and play a piece of music without mistake, as well as a comparative measure of degree of talent, such as the difficulty level of the music or the quality of playing in comparison to other pianists.

Consequently, Nietzsche's quantitative view of power measures power not simply according to quantity of ability, strength, or influence, but as superiority over others: it requires inequality and is increased only through the decrease of another's power - either relatively, through an increased power inequality that does not directly affect another's absolute level of power, or directly, through an absolute decrease in their quantitative power.

This sense of power is the more explicit one in Nietzsche's texts, leading many commentators to interpret all of his references to power along these lines. ${ }^{15}$ For example, when Nietzsche defines life 'in its basic functions' as 'assault, exploitation, destruction' (GM II: 12) or asserts that life is 'essentially appropriation, injury, overpowering' (BGE 259), he is clearly assuming the

13 BGE 260 and EH I: 7

14 BGE 19, 225, and 260; A 1, E H III: 'Zarathustra' 3.

15 See, for example, Arthur Danto, Nietzsche as Philosopher (New York: Columbia University Press, 1965), pp.158-63; R.J. Hollingdale, Nietzsche: the Man and his Philosophy (Cambridge: Cambridge University Press, 1965), pp. 185-6; Walter Kaufmann, Nietzsche: Philosopher, Psychologist, Antichrist (Princeton: Princeton University Press, 1950); and, more recently, John Richardson, Nietzsche's New Darwinism (Oxford: Oxford University Press, 2004). Each, in his interpretation of the 'will to power,' treats power as intrinsically a form of domination of the outside world. While this is the common view, the essential connection of power to domination in Nietzsche's views has usually been taken for granted without argument, since Nietzsche so often speaks of power in connection with domination. This is no accident: this is a common consequence of power, but the question for our purposes is whether or not it is a necessary consequence.

JOURNAL OF MORAL PHILOSOPHY 12 (2015) 1-32 
quantitative view. For, since power is not simply quantity but superiority, assault and injury are not mere accidents of life's basic function of growth, but its essence: there is no growth in power except at the expense of another's; there is no increase in quantity of power except through the reduction of another's. Consequently, quantitative superiority of power has some level of inequality as its precondition.

In striking contrast, qualitative power has some degree of equality as its precondition. Qualitative power is 'the feeling that power increases - that a resistance is overcome' (A 1). It is measured as intensity of feeling rather than as quantity of ability, so an agent is powerful in this sense to the degree that she feels powerful. ${ }^{16}$ And this feeling, in turn, depends not directly upon superiority of power, but upon relative equality. The agent feels power insofar as she is equal to a task, able to perform it, capable of overcoming obstacles to it. I will refer to this form of equality as proportionality. A relation is proportionally equal if any degree of inequality is 1 ) non-debilitating, allowing all agents to act with some degree of success, 2) non-dominating, allowing all agents the possibility of sometimes acting with a high degree of success and 3) non-demoralizing, allowing all agents the possibility of feeling powerful in the relation.

An ideal example of proportional power is athletic competition. For example, in the game of tennis, it is preferable that no player be so superior in ability that no competitor could conceivably score any points (non-debilitating), or occasionally win the match (non-dominating), or at least play competitively, winning a set or game (non-demoralizing). In this way, satisfying athletic competition requires a relative, rather than absolute, equality of ability: no individual should be invincibly, overwhelmingly, or hopelessly superior in ability.

In 'Homer's Contest,' Nietzsche directly praises such proportionality, comparing it to Hesiod's notion of 'good Eris' or strife, exemplified in the ancient practice of ostracism:

The Ephesians express it in their banishment of Hermodorus: 'Among us no one should be the best; but if anyone is, then let him be elsewhere and among others.' Why should no one be the best? Because with that the

16 Note that we cannot distinguish the qualitative and quantitative forms of power as simply relative and absolute or subjective and objective. For the quantitative sense of power, as superior or inferior quantity, is also relative. And as an assessment of superiority, of powerfulness relative to another or to one's own prior state, it is a secondary relational property (being more-powerful-than), thus not independently possessed. Just as height is an objective property, but tallness is not, so power (as mere quantity) is objective, but powerfulness (as relative quantity) is not. 
contest would dry up and the perpetual source of life of the Hellenic state would be endangered. ${ }^{17}$

In later writings, Nietzsche often fails to make the distinction between qualitative and quantitative power explicit; consequently, his commentators often underemphasize or overlook it. ${ }^{18}$ However, it is crucial to Nietzsche's moral psychology, since it emphasizes the subject's self-awareness of power and the relation of that awareness to the incentive to enhance power. If he does not consistently emphasize the qualitative side of power, it is nevertheless a constant theme, usually implied rather than directly discussed. As we have seen, Nietzsche associates the feeling of power with the overcoming of resistance or opposition. So Nietzsche's frequent discussions of resistance and opposition imply the qualitative conception of power.

For example, in Thus Spoke Zarathustra, Nietzsche emphasizes resistance not only as a means to the feeling of power, but as an end in itself, saying that life must be 'a resistance to ends (der Zwecke Widerspruch),' as well as 'struggle and a becoming and an end' (Z II: 12). Power is identified, not simply with the overcoming of an obstacle, but also with a struggle with resistance (the feeling of power) and the desire for such struggle (the will to power):

Every strong nature. ... needs objects of resistance [Widerstände]; hence it looks for what resists [Widerstand].... The strength of those who attack can be measured in a way by the opposition [Gegnerschäft] they require: every growth is indicated by the search for a mighty opponent. ${ }^{19}$ (E 1: 7)

Nietzsche's late works are full of such references to qualitative power, indirectly evoked through the language of resistance. Consider, for example, his description of decadence as an incapacity for resistance:

17 Friedrich Nietzsche, 'Homer's Contest,' trans. C. D. Acampora, Nietzscheana, 5, [1871] 1995, pp. 1-8.

18 Two admirable exceptions to this tendency are Richardson (Nietzsche's System, p. 162) and Bernard Reginster (The Affirmation of Life: Nietzsche on Overcoming Nihilism, Cambridge: Harvard University Press, 2006), both of whom recognize, in Nietzsche's emphasis upon overcoming and resistance in the will to power, the importance of the psychological, affective dimension of Nietzsche's understanding of power.

19 Nietzsche's affirmation of suffering is best understood in this light: suffering is not instrumentally good as a means to the end of the quantitative increase of power, ability, or achievement, but rather an intrinsic good, inseparable from qualitative power: suffering understood not as pain or sorrow, but rather as passivity to, the undergoing and feeling of,

JOURNAL OF MORAL PHILOSOPHY 12 (2015) 1-32 
Instinctive exclusion of all aversion, all enmity, all feeling for limitation and distancing: consequence of an extreme capacity for suffering and irritation which already feels all resisting [Widerstreben], all need for resistance, as an unbearable displeasure. ${ }^{20}$ (A 30)

Although Nietzsche also uses 'begegnen' (to encounter, resist, or oppose) and 'widersprechen' (to contradict) when speaking of resistance, it is 'widerstreben' (literally, to strive against) that best captures the qualitative conception of power as affect: the subject's power lies not in just any form of opposition, but in the feeling of actively resisting, of 'striving against' a resistance. At the same time, 'der Widerstand' (literally, what stands against) - a description of the obstacle rather than the act of resistance - perfectly captures the connection of power to equality. For the activity of resisting requires worthy opponents, resistances that can 'withstand' our activity, in order to produce the feeling of power.

Consequently, Nietzsche's conception of resistance, as a relational concept joining subject and activity (widerstreben) to object that withstands (der Widerstand), provides us with a unique conception of equality as proportional opposition or resistance, a form of equality Nietzsche repeatedly refers to, but never clearly distinguishes from the equality of similarity (die Ähnlichkeit) that he rejects:

The task is not simply to master what happens to resist, but what requires us to stake all our strength, suppleness, and fighting skill - opponents that are our equals. Equality before the enemy: the first presupposition of an honest [rechtschaffnen] duel. (E H 1: 7)

To clarify this positive relationship of qualitative power and equality as resistance, let us consider our tennis example in more detail. The player's qualitative power depends on the proportionality of her ability to a resistance. For example, a beginning tennis player who is fully capable of playing a competitive match, even if at a functionally low level, will feel a sense of power in the

resistance. Contrast, for example, the instrumental interpretation of the value of suffering in Leiter, 'Morality Critics,' pp. 269-71 and Hurka, 'Nietzsche: Perfectionist,' p. 17.

20 For more on resistance, see TI 5:3 on the spiritualization of enmity; ті 9:38 on resistance (der Widerstand) as the measure of freedom; BGE 200, where Nietzsche contrasts those who desire the end of contradiction and struggle to those for whom opposition is an incentive to life; and BGE 260 on master morality's pleasure in the feeling of resistance, 'the feeling of fullness, of power that seeks to overflow, the happiness of high tension.' 
exercise of this ability alone, even when she loses a point, a set, or the entire match. To be sure, when she loses, the power felt in the exercise of her basic ability may be outweighed by a stronger sense of powerlessness in relation to her opponent. But she will experience both momentary feelings and a general feeling of power in addition to those feelings of powerlessness. Every successful enactment of her basic ability - each successful serve, each hit returned - will be accompanied by feelings of accomplishment.

Measured in a strictly quantitative way - say, the number of matches won, the speed of her serve, the number and accuracy of her returns - her power is negligible. Measured according to superiority, she may have no power at all: she may well be inferior in degree of ability to every other tennis player. Nevertheless, in a competitive game - a game in which she possesses ability proportional if not equal to that of her opponent - she does possess power and will feel that power's qualitative effect. She is affectively aware of a real capability, of being equal to the task, in relation to both the component activities of the game and in relation to her opponent. By acting effectively (even in a losing game) in the face of proportional resistance from her competitor, she both possesses power (competitive ability) and experiences its effectiveness (the affect of power) ${ }^{21}$

Although the qualitative sense of power presupposes some degree of ability, a quantitative level of power, it does not directly correspond with either increase or superiority, and is best maintained through proportionality. More importantly, it exhibits a negative relation to radical inequalities of power. Qualitative power is not only maintained through proportionality, but diminished through increased superiority. True, degree of ability is not irrelevant. In our example, a tennis player must be relatively equal in power to her opponent in order to experience a feeling of power. The match must be competitive; she cannot lose every point; there must be a reasonable practical possibility of winning.

However, at the same time, her ability cannot be vastly superior to her opponent's. If there is no challenge, no possibility of failure, then the feeling of power will be dramatically diminished. For it is the active exercise and testing of ability, the feeling of effort in contrast to resistance, that is the basis of the affective side of power. ${ }^{22}$

21 For this reason we might doubt the common moralistic reading of the cliché, 'it is not whether you win or lose, but how you play the game.' This sentiment needn't be a reduction of sport to an opportunity to demonstrate moral character, but instead an important point about the intrinsic value and purpose of games: the pleasure, the feeling of power that the game provides, does not directly depend on whether you win or lose. 
Consequently, not only is the promotion of each individual's qualitative power compatible with that of every individual, the promotion of any individual's power requires the overcoming of radical power inequalities. For power requires proportional, if not absolutely equal, power among opposed agents. ${ }^{23}$ The power of each individual requires both opposition, obstacles against which power is tested, and relatively equal, proportional power among agents.

\section{Against Qualitative Equality: Ähnlichkeit or Vielheit, Similarity or Multiplicity?}

We have seen that Nietzsche uses the language of power in two distinct senses: as quantitative superiority of power and as qualitative proportionality of

example, William Connolly, Political Theory and Modernity (Ithaca: Cornell University Press, 1993), Bonnie Honig, Political Theory and the Displacement of Politics (Ithaca: Cornell University Press, 1993), Lawrence Hatab, A Nietzschean Defense of Democracy: An Experiment in Postmodern Politics (Chicago: Open Court Press, 1995), and Herman Siemens, 'Nietzsche's Critique of Democracy,' Journal of Nietzsche Studies 38 (2009), pp. 20-37. However, my purpose in highlighting resistance is, in contrast to their interest in Nietzsche's democratic possibilities, to emphasis the connection of power to equality. I should note that if Nietzsche is able to consistently endorse egalitarianism, it does not follow that he can endorse democracy or liberalism. Indeed, my interpretation may suggest a more radical, non-procedural form of egalitarianism incompatible with both. For a related view, see Mark Warren's suggestion that equal rights might be problematic for Nietzsche only given an absence of power equality: 'Equality of rights is possible only where there is de facto equality of the capacity to act. Nietzsche does not, then, oppose political cultures that include equal rights. But he does hold that rights will function ideologically if they lack a basis in a rough equality in individual capacities for action - a condition generally not met in liberal-democratic societies' (Nietzsche and Political Thought, Cambridge: MIт Press, 1988, p. 72).

23 In this respect, I agree with Hatab's claim that, for Nietzsche, ability is not entirely separable from superiority of power, that 'power-for cannot be separated from power-over' (Nietzschean Defense, p. 50). However, I disagree with his attempt to preserve the democratic possibilities in Nietzsche's thought by rejecting egalitarian readings of both Nietzsche and democracy (pp. 57 and 106-8). On my reading, the concept of relative or proportional equality is not simply compatible with, but essential to, Nietzsche's understanding of power. While the feeling of power coincides with forms of overpowering - as Hatab says, 'Self-expression and self-development never leave the world untouched' (p. $5^{0}$ ) - nevertheless, relative equality is a necessary condition for the feeling of power, and the degree of relative equality grounds the intensity or strength of the feeling of power. Consequently, to discard the issue of equality is to disregard the principal foundation of Nietzsche's theory of power. Warren has presented a similar defense of the egalitarian 
power. We have also discovered that each form of power has a very different relationship to equality. Quantitative power increases relative to a decrease in others' power, necessitating inequality among agents. Qualitative power, in contrast, requires proportionality, a relative equality allowing only for nondisabling, non-dominating, and non-demoralizing degrees of inequality.

I will now argue that Nietzsche's frequent conflation of these two conceptions leads him to mistakenly endorse an unqualified anti-egalitarianism. If we hold him to his prioritization of qualitative over quantitative power, his arguments will require the rejection only of qualitative equality as similarity (die Ähnlichkeit), a position that is consistent with, even dependent upon, equality as multiplicity (die Vielheit), based in the relative equality of multiple proportional resistances (die Widerstände). ${ }^{24}$

Nietzsche's rejection of egalitarianism is grounded in the belief that it is harmful to the promotion of the highest individuals, that it benefits the majority at the expense of the most valuable. He presents two kinds of arguments in favor of this view: first, that equality is directly harmful in aim to the promotion of higher human beings and, second, that it is indirectly harmful in consequence rather than aim. ${ }^{25}$ The former kind of criticism presupposes a narrow definition of egalitarianism as the direct expression of what Nietzsche calls slave morality: a morality that originates in the resentment of privilege, expressed in vengeful values that seek to reduce the power and happiness of the most fortunate. I will call this the slavish form of egalitarianism, to be

implications of Nietzsche, though he focuses on the relation of equality to power as capacity to act, rather than as the feeling of power (Nietzsche and Political Thought, p. 218).

24 I should note that this paper only considers the compatibility of normative, not descriptive, egalitarianism with Nietzsche's normative goal of promoting higher individuals. The question is whether Nietzsche can consistently seek to promote equality as an end, and not whether he can affirm the descriptive claim that all human beings are in some sense identical in essence or equal in value or deservingness of respect. I leave this question aside, in part, because it is outside of the scope of the paper's focus on normative ethical theory, but also because I doubt that Nietzsche's moral anti-realism can support any substantive or strong claims about value or worth, whether egalitarian or anti-egalitarian.

This distinction of morality as directly harmful in aim and indirectly in consequence is somewhat comparable to Leiter's distinction of the critique of morality as theory and as cultural practice, since morality's aims are explicitly, theoretically articulable demands made upon subjects, while the consequences of a culture's adoption and practice of a morality may not be contained in explicit doctrines or conscious aims ('Morality Critics,' pp. 280-85). Leiter's principal goal in making this distinction is to distance Nietzsche, as a critic of morality as a practice, from contemporary critics of morality as theory, so he does not, as I will do, question whether Nietzsche's claims of morality's harm to higher individuals, as both theory and practice, are either consistent or reasonable.

JOURNAL OF MORAL PHILOSOPHY 12 (2015) 1-32 
distinguished from the possibility of a 'noble' form of egalitarianism, one compatible with the spiritually aristocratic value of promoting humanity's highest individuals. Slavish egalitarianism is assimilationist; it seeks to establish qualitative equality, understood as similarity. Noble egalitarianism, in contrast, is pluralist; it supports only quantitative equality - proportional resistance as the foundation of qualitative multiplicity - thus it is anti-egalitarianism in the slavish sense.

The distinction of noble and slavish egalitarianisms is not my own invention. Nietzsche draws it explicitly in middle period works like Human, All Too Human:

The thirst for equality can express itself either as a desire to draw everyone down to oneself (through diminishing them, spying on them, ripping them up) or to raise oneself and everyone else up (through recognizing their virtues, helping them, rejoicing in their success). ( $\mathrm{HH}_{300}$ )

It also appears in The Wanderer and his Shadow, where he again contrasts Hesiod's 'bad Eris,' in which the man one envies 'exceeds the common measure' and so one 'desires to push him down to it' with the 'good Eris' of 'nobler natures,' in which an individual seeks 'to raise himself up to the height of the other' (WS 29).

Although explicit references to a beneficial egalitarianism disappear in Nietzsche's later work, he still implicitly acknowledges its possibility. For example, in Beyond Good and Evil, when he worries that ' 'equality of rights' could all too easily be changed into equality in violating rights,' he implies the possibility of an equality that is not so changed, and so does not violate rights (BGE 212, italics mine).

But when Nietzsche attacks the ideal of equality as directly harmful to human flourishing, he ignores the distinction. He objects to equality as a form of assimilation, 'a certain actual rendering similar [Anähnlichung] of which the theory of 'equal [gleichen] rights' is only an expression,' targeting only the narrow, slavish sense of egalitarianism. In such arguments, he is committed to rejecting only attempts to make 'equal' in the narrow sense of making qualitatively identical - to impose a qualitative similarity of type, value, and life, and not quantitative similarity of ability, power, or right (TI 9: 37$){ }^{26}$

26 Many interpretations that accept Nietzsche's self-assessment as anti-egalitarian in a strong, unqualified sense fail to give sufficient attention to this distinction of qualitative and quantitative senses of equality. See, for example, Leiter, 'Morality Critics,' Hatab, Nietzschean Defense, and Bruce Detwiler, Nietzsche and the Politics of Aristocratic 
This critique of anti-egalitarianism is based, in other words, in his commitment to pluralism of human values and types. ${ }^{27}$ Equality defined as identity or similarity - a connation more pronounced in the German 'Gleichheit' (literally 'sameness' or 'likeness') - is harmful to 'the pathos of distance' understood in an equally narrow sense: as a feeling for qualitative difference, for 'the multiplicity [Vielheit] of types, the will to be oneself, to stand out.'28

While Nietzsche does suggest that the demand for political equality (which ignores 'the chasm between man and man, class and class') is symptomatic of a general cultural desire for uniformity, it is the latter narrow tendency against multiplicity (Vielheit) and diversity (Vielfältigkeit) that is the direct source of harm to higher human beings. Nietzsche's demand for qualitative inequality of worth - differing mutual evaluations of persons, values, and types - is not, then, directly a demand for quantitative inequality of political right, economic or class status, ability, or talent. ${ }^{29}$

Radicalism (Chicago: University of Chicago Press, 1990), although Siemens' 'Nietzsche's Critique of Democracy' is a helpful corrective to this oversight. Hatab claims that Nietzsche's primary target is egalitarianism, but described as 'the weak majority grabbing power to incapacitate the strong few, a very narrow sense distinct from the form I will propose (1995: p. 28). Hatab also rightly insists upon the incompatibility of strong claims about the substantive equality of persons with Nietzsche's views (Nietzschean Defense, pp. 22-24 and 57-61). However, my argument concerns equality only as a practical aim of justice, not as a substantive claim about human nature or worth. Detwiler, in his ambitious interpretation of Nietzsche's thought as an 'aristocratic politics,' makes a strong case for Nietzsche as an anti-egalitarian of a limited variety. However, in marshaling textual evidence of equality's supposed dangers to the enhancement of the highest individuals, he does not distinguish the differing narrow senses of equality at issue. In most of these cases, Nietzsche's critique of equality is indistinguishable from his critique of slave morality, objecting to egalitarianism on the assumption that it is inseparable from revenge against the higher and pity for the lower, as the condemnation of suffering and self-interest, and so on. But this fails to show that a demand for equality must contain any of these objectionable characteristics.

27 See, for example, тi 5: 6.

28 Compare BGE 212, where, again in contrast to qualitative egalitarianism, Nietzsche applies this pluralistic ideal of Vielheit to the individual soul, describing an individual's greatness as 'his range and multiplicity [Vielfältigkeit, diversity], his wholeness in manifoldness [in seine Ganzheit im Vielen zu setzen].... Greatness: being capable of being as manifold [vielfach] as whole, as ample as full.'

29 Maudemarie Clark and Lawrence Hatab both defend a similar point about the independence of qualitative and quantitative equality: namely, that Nietzsche's rejection of the equal value of persons does not require the rejection of the political equality of persons, since certain kinds of equality, such as the limited political equality implied by a

JOURNAL OF MORAL PHILOSOPHY 12 (2015) 1-32 
Against Quantitative Equality: Pathos of Distance as Superiority or Difference?

Of course, Nietzsche's case against equality does not depend only on the claim of direct harm. He also believes that equality indirectly harms the promotion of higher types, a claim that may apply to all forms of egalitarianism. His criticism focuses on three causally interrelated conditions for the promotion of higher types: material and political inequality, the cultural dominance of aristocratic values, and a narrower sense of the 'pathos of distance' as belief in, and a feeling for, superiority (an equivocal, quantitative sense of 'pathos of distance' grounded in Nietzsche's equivocal use of 'power'). He claims that 'every enhancement of the type 'man' has so far been the work of an aristocratic society - and it will be so again and again' (BGE 257).

However, this apparent claim of a direct causal link between political inequality and human enhancement is quickly qualified. An aristocratic society, he says, is one that 'believes in the long ladder of an order of rank and differences in value between man and man, and that needs slavery in some sense or other.' So, the direct cause of human improvement is not political inequality, but aristocratic beliefs and values. Indeed, he goes out of his way to qualify the language of slavery, the context clearly indicating psychological rather than political subordination and obedience. ${ }^{30}$ As the passage continues, this shift

commitment to democratic institutions 'need not depend on the belief that persons are of equal worth' (Maudemarie Clark, 'Nietzsche's Antidemocratic Rhetoric,' Southern Journal of Philosophy 37, 1999 suppl., pp. 119-41). Clark argues that Nietzsche has not explicitly claimed otherwise, while Hatab thinks Nietzsche has failed to recognize the compatibility of value inequality with certain forms of political equality (Nietzschean Defense, p. 114). Both, however, agree that the proper target of Nietzsche's criticism is equality rather than democratic political institutions - thus redeeming democracy for Nietzsche at the expense of equality (Clark, 'Antidemocratic Rhetoric,' p. 133 and Hatab, Nietzschean Defense, p. 57). While I will not consider the question of democracy's compatibility with Nietzsche's value philosophy, I do think this fails to acknowledge the specific and narrow form or sense of equality that is immediately problematic for Nietzsche: equality as the reduction of multiplicity to similarity, rather than as the reduction of material, economic, and political inequality. I will argue that only the former is problematic for Nietzsche.

30 Clark emphasizes this point as part of her argument that Nietzsche is explicitly committed only to the view that although social hierarchy was an historically necessary condition for the development of a spiritual pathos of distance, it is no longer necessary ('Antidemocratic Rhetoric,' p. 130). David Owen makes a similar claim in 'Equality, Democracy, and Self-Respect: Reflections on Nietzsche's Agonal Perfectionism' (Journal of Nietzsche Studies 24, 2002, pp. 113-31), arguing that in the slave's inward redirection of 
from material to psychological and evaluative conditions is repeatedly underlined:

Without that pathos of distance which grows out of the engrained difference between strata ... that other, more mysterious pathos could not have grown up either - the craving for an ever new widening of the distances within the soul itself, the development of ever higher, rarer, more remote, further-stretching, more comprehensive states - in brief, simply the enhancement of the type 'man,' the continual 'self-overcoming of man.' (BGE 257)

So material inequality is a necessary precondition for a culture of aristocratic values, which is in turn necessary for the production of the pathos of distance in two forms: first, as a feeling of social superiority and, second, as a feeling of self-superiority - the basis of any incentive toward self-overcoming or self-improvement.

Now, if this claim is plausible, it is so only if we understand human enhancement on the model of power as quantitative superiority. In the passage, enhancement is defined as the self-overcoming of human beings, indicating that an individual's value is measured according to comparative quantity of ability or achievement, as superiority to other individuals or to an individual's own previous states, not according to ability or power simply. For the demand for continual self-overcoming and 'ever higher' states indicates that no degree of excellence or ability has any intrinsic worth: only the supersession of a given quantity matters in the assessment of human value. ${ }^{31}$

Second, this conception of enhancement focuses on quantitative rather than qualitative power. To be sure, it culminates in a feeling of superiority, but one tied directly to quantity: a sense of the quantitative distance between one person or state and another. So the pathos of distance is a feeling of power defined as quantitative superiority: the sentiment of possessing greater power, ability, or worth in relation to others or to previous states of the self. ${ }^{32}$

ressentiment, the 'pathos of inner distance,' or the 'reflexive ethical relationship of the self to itself,' becomes independent of the 'pathos of social distance,' the recognition of social rank. This, in turn, creates 'the possibility of a form of noble morality in which the consciousness of power is similarly not predicated on relations of social hierarchy' (p. 124).

31 I develop this suggestion of the non-intrinsic value of enhancement in more detail in section 9, below.

32 It is also worth emphasizing that this form of the 'pathos of distance' is a perfect analogue of the slavish mode of value creation that Nietzsche critically presents in On the Genealogy

JOURNAL OF MORAL PHILOSOPHY 12 (2015) 1-32 
Assuming this conception of power and flourishing, Nietzsche's anti-egalitarianism is no mere prejudice. It is at least plausible, if not entirely convincing, that a desire to produce higher states in oneself requires recognizing spiritual superiority and inferiority in others, a recognition that, in turn, might depend upon the recognition of quantitatively measured inequalities, whether of wealth, power, or right. If so, then it might be true that aristocratic societies enhance the pathos of distance as superiority, promoting the pursuit, among the most able, of states of greater excellence. And it might, further, be possible - albeit, again, far from evidently true - that a society of relative equality would be characterized by individuals with a weaker pathos of distance - a weaker belief in differences in individual worth - and, consequently, with a lack of incentive toward achievement or excellence.

However if, on the contrary, we do not take for granted the quantitative conception of power as superiority, and instead hold Nietzsche consistently to the priority of qualitative, proportional power, this argument against egalitarianism fails. Qualitative power is measured as the degree of the feeling of power that accompanies successful action. Individuals can achieve and enhance this form of power without possessing superior ability, indeed, without even believing themselves to be superior in power.

of Morality. As in slave morality, one's well-being is measured through the 'reversal of the value-establishing glance ... toward the outside instead of back onto oneself,' in contrast to the noble self-evaluation of the well-born who "simply felt themselves to be the "happy" and 'did not first have to construct their happiness artificially by looking at their enemies, to talk themselves into it' (GM I: 10). It is also no coincidence that in the same passage Nietzsche identifies the slavish mode of evaluation with anti-egalitarianism in the narrow sense of anti-pluralism: 'Slave morality says 'no' to an 'outside,' to a 'different,' to a 'notself.' This is our first clue, which I explore in more detail below, that Nietzsche's opposition to qualitative equality is, in fact, compatible with quantitative egalitarianism: that the cultivation of Vielheit as proportional resistance, a form of equality, is inseparable from the condemnation of Gleichheit as assimilation, as the harmful, slavish mode of egalitarianism. Nietzsche makes a similar point in Human, All Too Human 457, where he criticizes a form of egalitarianism based, not in the demand for equality as human dignity, but rather as 'vanity, which experiences Not-being-equal-to or Publicly-being-esteemedlower as the harshest fate.' Here the demand for equality is, like the demand for quantitative superiority of power, not a desire for the feeling of power, but for comparative superiority of power in relation to another, a self-affirmation through comparison to and devaluation of another. See also 'Assorted Maxims and Opinions,' where he identifies a false pathos of distance, a prosperity that is excessively 'external and provocative of envy,' indicating not true 'well-being' but 'spurious, histrionic' pleasures 'which lie more in the feeling of contrast (because others do not have them and feel envious) than in feelings of realized and heightened power' (HH, 'Assorted Opinions and Maxims,' 304).

JOURNAL OF MORAL PHILOSOPHY 12 (2015) 1-32 
In my example, a beginning tennis player felt power in being relatively equal to the game and to her competitor, a feeling based in proportional rather than superior power. Consequently, enhancing the qualitative feeling of power does not require a 'pathos of distance' - at least not of 'distance' understood as evergreater superiority to oneself or others. And, consequently, neither aristocratic values nor social conditions are required for the promotion and enhancement of power. Our tennis player need not believe that her abilities have improved to feel powerful in her playing, nor does she need to believe that she is substantially more able than her competitors. ${ }^{33}$

Here we must be wary of Nietzsche's quantitative, spatial metaphors for the pathos of distance ('widening,' 'higher,' 'further,' etc.), which imply that power increases in direct correlation with quantitative superiority over a previous state or another person. As we saw in Nietzsche's critique of equality as assimilation, the pathos of distance is first and foremost one of qualitative distinction rather than superiority. The feeling of power depends not on unequal quantities of power, but rather on proportional, oppositional resistance.

But disproportionately unequal abilities produce less resistance and, consequently, little feeling of power. What 'heightens the feeling of power' (recalling that Nietzsche directly defines this as the 'good,' above the will to and attainment of power), what intensifies the pathos of distance, is not the expansion of inequalities, but the qualitative increase of oppositional intensity. That is, the pathos of distance is enhanced by 1) promoting the quantitative increase in human powers and abilities generally, 2) promoting proportional power among agents, and 3) promoting a multiplicity of oppositional powers that can serve as resistances to one another, grounding the feeling of power as the feeling of resistance. ${ }^{34}$

Consequently, we may draw a first key conclusion about the relationship between equality and human flourishing: the promotion of equality does not necessarily harm the pathos of distance. The promotion of equality in the form

33 This claim might, at first glance, appear to be empirically false: do not athletes seek to feel the improvement of their abilities? While this is true, it is consistent with proportionality: successful athletes require increasingly more challenging opponents and so must improve their ability to preserve proportionality with new opponents. The feeling of power, then, comes not from superiority (to opponents or to prior states), but from proportionality. I discuss the issue of qualitative power, increase of power, and the incentive to develop power in more detail in the next section.

34 Compare H. W. Siemens' suggestion that Nietzsche's principal objection to democracy lies in its failure to cultivate pluralism: 'It is that Nietzsche doubts - while expressing democracy's claim to be the site of genuine pluralism; and without genuine pluralism, there can be no genuine freedom for Nietzsche, no effective resistance to tyranny, be it a single genius or a singular 'people" ('Nietzsche's Critique of Democracy,' p. 25).

JOURNAL OF MORAL PHILOSOPHY 12 (2015) 1-32 
oppositional, proportional resistance preserves this pathos as awareness of qualitative difference rather than superiority of wealth, status, or privilege. Not only does egalitarianism not destroy this form of the pathos of distance, material inequality diminishes it. Increased inequality undermines the pathos of distance, because the ablest individuals will find fewer opportunities to test their abilities against resistances of proportional power. ${ }^{35}$

\section{$5 \quad$ Against Egalitarianism as Liberalism: Aristocracy as Qualitative or Quantitative Power?}

My interpretation of qualitative power's relation to equality also has the virtue of more fruitfully explaining Nietzsche's anti-liberalism. Nietzsche frequently insists upon constraint, in contrast to negative liberty, as a precondition of human enhancement, a demand that some interpreters such as Bruce Detwiler view as evidence that he favors an aristocratic politics. ${ }^{36}$ Nietzsche says, for example, that liberal institutions 'undermine the will to power, they are the leveling of mountain and valley exalted to a moral principle' and that 'the highest type of free man' should be sought 'where the greatest resistance is constantly being overcome: five steps from tyranny, near the threshold of the danger of servitude' (TI 9:38). The source of the decadence of modern humanity is, he argues, a profound conflict of instincts that 'contradict, disturb and destroy one another' to such a degree that 'today the only way of making possible the individual would be by pruning him' (TI 9: 41).

35 Siemens makes a similar point: 'The agon, if it is to be a nondestructive and productive conflict among more or less equals, depends not just on relations of reciprocal provocation and stimulation but also on relations of reciprocal limitation. The later Nietzsche, then, does not regress to his early standpoint in genius and the ideal of self-limitation; rather, in conceiving the 'higher' or 'exceptional beings' in pluralistic, agonal terms, he returns to his central insight: that the best source of limits on the genius is 'a second genius,' that is, a plurality of more or less equal geniuses or forces' ('Nietzsche's Critique of Democracy,' p. 31). While this preserves the distinction between the agonistic, mutually enhancing competition of a higher few in contrast to the inferior many, the crucial point is that their feeling of power, and their incentive to greater achievement, depends upon their relation to one another as proportional powers, not upon their superiority - or pathos thereof - to the rest of humanity.

36 For example: 'Nietzsche's and Zarathustra's goal, which is the elevation of man, is fraught with political consequences. It would appear that this goal cannot be achieved without a reversal ... of the democratic tendency that characterizes the modern world in favor of aristocratic social and political arrangements' (Detwiler, Nietzsche's Aristocratic Radicalism, pp. 45-46). 
However, if we treat such passages as objections to egalitarianism as well as to liberalism, they are no longer plausible. Nietzsche thinks that individuals are enhanced through relative constraint: through the overcoming of resistance and the continual presence of proportional resistances. An aristocratic politics, by politically institutionalizing and enforcing radical inequalities of power, does produce constraints, but only directly upon the subordinate class.

Thus, if political inequality enhances human beings, it enhances the lower at the expense of the higher. It does not, as Nietzsche must really intend, create productive resistance for the highest. On the contrary, an aristocratic politics eliminates counter-powers to the ruling class. Surely, we are not to find in a political aristocracy those free beings 'near the threshold of the dangers of servitude'? Aristocratic inequality cannot, on Nietzsche's argument, enhance the power and ability of the highest, since it removes resistance precisely away from the higher and to the lower. Nor can it be said to enhance the ruled, as an indirect means for producing rare, higher individuals. For an aristocracy does not impose upon the lower class a proportional political power; it does not provide mere constraint or discipline, a resistance conducive to enhancement, but rather subjugation and impotence - the end of all capacity for resistance. It is not 'five steps from tyranny,' but tyranny simply.

Consequently, Nietzsche's critique of liberalism is consistently interpreted only as a critique of the attempt to remove all constraints and obstacles, to abolish power altogether, including proportional counter-powers and resistance. This, in turn, is a critique that can be applied only to the slavish form of egalitarianism: the universal reduction of all power and resistance, the promotion of equality as similarity and the absence of opposition.

But it does not apply to the noble form of egalitarianism that I have developed from Nietzsche's qualitative theory of power: the proportional promotion of every individual's power as a means to the cultivation of oppositional counter-powers, an egalitarianism that produces the very conditions of constraint that Nietzsche believes necessary to the cultivation of greater human types. An egalitarianism based in the affirmation of oppositional resistance as the ground of human enhancement, rather than in the negation of all power as limitation, does not promote the laissez-faire form of liberalism Nietzsche critiques, and so it need not harm the pathos of distance.

\section{Against Equality as Complacency: Will to Domination or Will to Resistance?}

Even if egalitarianism does not harm the enhancement of humanity directly by reducing the pathos of distance, it might be argued that it does so indirectly, 
by reducing the psychological incentive to achieve higher states. For I have interpreted the pathos of distance as a feeling of difference rather than superiority, on the grounds that that the pathos of superiority is inconsistent with Nietzsche's primary conception of power as the feeling of ability in relation to proportional resistance. It might be argued that a pathos of difference that lacks a pathos of superiority inevitably promotes complacency. For if power can be felt in relative equality and does not depend on superior quantity or degree of ability, then there is no psychological incentive to increase one's power, to heighten one's abilities or seek additional, greater achievements.

On the contrary, we may now draw a second key conclusion about the relation of equality to enhancement. Not only does proportional, oppositional equality not harm enhancement, it actively motivates and promotes it. Indeed, only on the qualitative interpretation of power is there such an incentive. Qualitative power motivates immediately: the present feeling of power experienced in the successful exercise of an ability motivates the individual to continue to exercise that ability. And this direct, immediate incentive to continue activity is, in turn, also an indirect incentive to improve the ability through its continued exercise.

Consider the example of learning to play a game. If I completely fail to understand how to play the game, feeling powerless in the process, I will quickly give it up. If, on the other hand, I immediately find it far too easy and unchallenging, I will grow bored and give it up. Finally, if I find it challenging but experience some success, I will be motivated to continue playing it. ${ }^{37}$ And by continuing to play the game, I will improve my playing skill. Consequently, proportional equality to the task provides a direct incentive to action and an indirect incentive to development of ability.

Contrast this immediate, affective incentive to develop ability to the quantitative model of power. On that model, the motive to enhance ability is indirect, a product of reflective judgment rather than immediate feeling - it is my desire for comparative superiority over others, a superiority only reflectively realized, in contrast to the immediate affective knowledge of qualitative power, that provides an incentive to excel. In the case of an agent of inferior power acting in the face of superior obstacles, the lack of proportional resistance produces a feeling of impotence, a disincentive to continue to act. ${ }^{38}$ In the case of

37 Compare Bernard Suits' description of the gamewright's craft in The Grasshopper: Games, Life and Utopia (Toronto: Broadview Press, 2005) pp. 44-45.

38 Note, again, that the quantitative form of power mirrors the slavish form of evaluation. In the case of the weaker agent, the feeling - and reality - of practical impotence is a disincentive to self-development. Instead, it is a strong incentive to revenge: the reduction of the other's power, rather than the development of one's own.

JOURNAL OF MORAL PHILOSOPHY 12 (2015) 1-32 
an agent of superior ability, there is, again, a lack of proportional resistance. In the absence of challenge or feeling of worthy competition, the agent of superior power experiences no feeling of power and thus no incentive to continue in the exercise of her abilities. Moreover, her reflective awareness of her complete superiority to any obstacle or competitor does not provide incentive but instead provokes complacency: her substantial superiority demonstrates that she has no need to further develop her abilities. ${ }^{39}$

So, we have seen that power equality motivates continued exercise of ability and secondary enhancement of ability through that exercise. Moreover, because this incentive is based in proportional power - the exercise of ability in the face of relatively equal resistances - as ability increases, the agent has an accidental incentive to find ever-greater challenges to meet, thus further heightening ability. In my example of successfully learning a new game, as my skill increases, decreasing the challenge and enjoyment, I will be motivated to seek out more challenging opponents or a new, more challenging game, further increasing my skills in the process. Qualitative power is not, then, a teleological desire for ever-greater levels of achievement (nor is Nietzsche's endorsement of power an inconsistent regression to teleological, essentialist, or progressive moral perfectionism), but rather a tendency toward the continual exercise of power in relation to proportional resistances, having the increase of ability and power and the seeking of ever-greater resistances as an accidental consequence of improvement through power's exercise. ${ }^{40}$

In this way, qualitative power promotes the quantitative increase of power. But it does so only given new obstacles, only if proportional opposing powers are cultivated. The tennis player in our earlier example is motivated by her feeling of power to continue in the exercise of her ability, and through continued exercise she improves that ability. However, if her competitors fail to improve their abilities to a comparable degree, the resistance upon which her feeling of power depends will be lost. She will be motivated to become a more skillful player only provided her competition becomes more skillful, as well.

39 Detwiler suggests that it is 'obvious why Nietzsche contends that the enhancement of the type 'man' ... will continue to be the work of an aristocratic society.... Because the political distinctions that are the defining characteristic of such societies give rise to spiritual distinctions, which in turn engender a perpetual and life-affirming striving for self-conquest and self-perfection' (Nietzsche's Aristocratic Radicalism, p. 119). While this is Nietzsche's position, it is far from obvious that this position should be taken seriously far from obvious that such distinctions do, in fact, engender any such striving.

40 For a more detailed account of this anti-teleological interpretation of the will to power, see section 3 of my 'Nietzsche's Will to Power as Naturalist Critical Ontology, forthcoming in History of Philosophy Quarterly 30: 2 (2013).

JOURNAL OF MORAL PHILOSOPHY 12 (2015) 1-32 
Consequently, it is strong anti-egalitarianism (opposition to both quantitative and qualitative equality, rather than only to qualitative similarity) that is harmful to the promotion of human powers. By cultivating radical inequalities in power, society reduces the incentive of both weak and strong to develop their abilities - the incentive of the feeling of power, based in proportional, oppositional power.

\section{$7 \quad$ Against Equality as Inefficient Enhancement: the Distribution Argument}

It might also be argued that equality is practically incompatible with human flourishing for simple economic reasons of efficiency: the improvement of humanity might be better served by the unequal allocation of economic resources and cultural support to the highest, most able individuals at the expense of others. Nietzsche makes this argument about the development of artistic achievement in an early essay, 'The Greek State':

In order that there be a broad, deep, and fertile basis for the development of art, the vast majority must, in the service of a minority, be slavishly subject to life's unpleasant exigencies beyond the measure of their individual need. At their expense, through their extra labor, that privileged class is to be exempted from the struggle for existence in order to create and satisfy a new world of necessity. ${ }^{41}$ (GSt)

We should note, first, that this is not strictly an argument against egalitarianism but for elitism. If correct, it suggests only that egalitarianism is a less efficient means of human enhancement, not that it is incompatible with human enhancement. So it would be compatible with my principle claim that Nietzsche's arguments against egalitarianism fail on the qualitative conception of power.

41 Similar arguments can also be found in HH 439 and BGE 258. Hurka makes this view, which he calls a 'maximax' principle (in contrast to John Rawls' maximin principle of maximizing the wellbeing of society's least fortunate), central to his reading of Nietzsche as a moral perfectionist ('Nietzsche: Perfectionist,' p. 18). Clark, in contrast, argues that Nietzsche does not continue to hold this view in his later work ('Nietzsche's Antidemocratic Rhetoric,' pp. 127-28). While I agree with Hurka that Nietzsche continues to hold the view, it is inconsistent with his qualitative theory of power and mistaken in its assumption that inequality practically promotes excellence. 
Second, this practical worry, like the logical one, is based in the quantitative theory of superiority of power. An unequal distribution of resources to the most able may have the immediate practical benefit of heightening the abilities of ever fewer individuals, but at the long-term cost of diminishing opportunities for resistance and thus diminishing both the incentive and ability of higher individuals to maintain and further develop their abilities. In contrast, in a society in which material cultural resources are devoted to the cultivation of proportionally equal abilities, any short-term diminishment in the development of the highest individuals will be outweighed by a greater long-term overall enhancement of human abilities through the continued preservation of proportional power. A steady, egalitarian enhancement of humanity as a whole would outpace the accomplishments of a self-defeating aristocratic society in which the psychological incentive of proportional power - of evergreater challenges to past achievement - is lost.

Nietzsche's explicit arguments against anti-egalitarianism are neither logically nor practically incompatible with a form of egalitarianism based in a consistent qualitative interpretation of power. Moreover, because the qualitative feeling of power depends not on quantitative inequality of power but instead on qualitative difference (oppositional human types, values, and ends), we can also conclude that the noble promotion of the proportional power of every individual is a form of egalitarianism consistent with, even conducive to, the narrower form of anti-egalitarianism that Nietzsche does endorse: the rejection of equality in the form of qualitative similarity. Noble egalitarianism, by promoting equality in the form of proportional, oppositional resistances, also promotes a multiplicity of human types and values, since proportional power enables differing individuals and groups to resist domination by one another.

Finally, it might be argued that there are forms of elitism that are compatible with both the anti-egalitarian allocation of resources and the preservation of proportional equality among elite members. This view seems to fit well with Nietzsche's own representation of Homeric Greece as an anti-egalitarian, agonistic society of equal elites, as well as his frequent depiction of noble morality as one that includes equal respect and treatment among peers (BGE 26o). Such an anti-egalitarianism society would not diminish the proportional equality of ability needed to promote resistance and the feeling of power. Thus Nietzsche could reject egalitarianism as the less efficient means of enhancing both the quantitative and qualitative aspects of human power. 
Let us call this alternative to egalitarianism progressive elitism: elitist because it unequally distributes resources, progressive because it has as its goal the absolute quantitative enhancement of human powers. The identification and promotion of an elite group is merely a means to that end and, consequently, progressive elitism may sacrifice the interests of current members for the sake of that end.

In contrast, conservative elitism produces an elite for its own sake and not for any further end. Consequently, the unequal distribution of resources to an elite is intended to protect and preserve the advantages of its members; it is not intended primarily to enhance those members or humanity generally. Broadly speaking, the progressive form advances a higher form of humanity through the cultivation of elite individuals, while the conservative form preserves a higher form of humanity through the protection of elite individuals.

It may be argued that progressive elitism is a more efficient means of human enhancement than egalitarianism, because it devotes greater resources to the cultivation of the most able. In doing so, it achieves the greatest absolute quantitative increase in individual abilities. Moreover, by placing the most able in competition with their peers, progressive elitism establishes a community of equals, thus promoting the highest levels of the feeling of and will to power. Therefore, as an efficient means to both qualitative and quantitative human enhancement, progressive elitism is superior to the broad, gradual promotion of power that characterizes egalitarianism.

However, even if this is correct, the progressive form of elitism is incompatible with Nietzschean strong anti-egalitarianism, since it makes use of egalitarian means in its promotion of an elitist end. Nietzsche defines his form of elitism as 'Equality for equals, inequality for unequals.' The 'true voice of justice' demands that we 'never make equal what is unequal' (TI 9: 48). An elite society identifies superior individuals, sacrificing humanity's resources, interests, and welfare to their interests (BGE 258), but it does not actively promote individuals' entrance into the elite. The goal is not to produce superiority but to separate it, not to directly cultivate higher individuals but to protect them. Consequently, Nietzsche's elite is not a means to the enhancement of humanity but an end in itself: 'the essential characteristic of a good and healthy aristocracy...is that it experiences itself not as a function (whether of a monarchy or a commonwealth) but as their highest meaning and justification' (BGE 258).

Progressive elitism, in contrast, cannot be reduced to the separation and protection of an elite. For its aim is the absolute increase of human powers. Admittedly, Nietzsche tries, inconsistently, to endorse both aims. Shortly after declaring a healthy aristocracy to be an end in itself, he adds that society is the 'scaffolding on which a choice type of being is able to raise itself to a higher 
task. Even the image of scaffolding suggests his elitism is one of protection not cultivation, it establishes conditions in which the higher type may 'raise itself,' rather than actively elevating individuals through elitist institutions. In any case, in his attempt to portray elitism as a means to human advancement, he fails to acknowledge that not only society but also the present elite must serve as the scaffolding for future higher types: the primary threat to the cultivation of a future elite is the power and desire for self-preservation of the members of the present elite. Consequently, the absolute enhancement of humanity may be hindered by the protection of a given elite, by the 'healthy' aristocracy's conviction that it is the meaning and justification of society. An elite that is an end in itself will merely preserve its present level of achievement rather than increase it, protecting superiority only relative to a given state of humanity's development.

Consequently, the progressive aim requires that members of the elite be chosen and promoted not only according to ability but also according to their potential to increase their abilities. And this, in turn, means that progressive elitism requires a system of selection that monitors potential as well as actual ability. Individuals with greater potential for development must be raised or cultivated into the elite, and once-superior individuals who decline in achievement or potential must be removed from the elite. Progressive elitism is a sorting mechanism to promote only those higher individuals who enhance their abilities and only for as long as they continue to do so.

Nietzsche's elitism, in contrast (like that of the classical aristocracies he so admires) is conservative in form. It identifies superior individuals not to improve them, but to protect them. It ensures the survival of those who happen to be relatively superior to the average, but does not continually sort or select to increase the probability of absolute human enhancement. It cannot, for to do so would require a limited form of egalitarianism. It requires that we do the one thing Nietzsche repeatedly claims we must not do: make equal what is unequal.

For, in order to promote the continual absolute enhancement of humanity, progressive elitism must continually identify and cultivate a future elite: those who will meet and exceed the achievements of the present - who are, consequently, as yet unequal in power and resources to the current elite, though potentially greater. And potential ability can only be identified through testing: individuals of unproven ability must be given the same opportunities as those of proven ability, the unequal made equal. The same, of course, is true of the cultivation of potential ability through practice: if practice is to enhance ability, it must strain it, again requiring that individuals encounter opportunities to which they have not yet proven themselves equal. The primary task of progressive elitism is, then, an egalitarian means to an elitist end: the wise 
investment of resources in these not-yet-equals, their transformation through testing and training into challengers to the elite status quo.

Consequently, progressive elitism not only defies Nietzsche's cardinal rule of 'inequality for unequals,' it also ensures that the reigning elite is an unstable class. New challengers will displace old, necessitating an additional, complementary form of limited egalitarianism: members of the elite, equal to other elites in privilege thanks to once equal accomplishments, must sometimes be made unequal, their privileges withdrawn when their abilities prove to be misjudged or outpaced. Progressive elitism seeks to create a risky, unstable, changing class of high-level competitors, and such an elite can be maintained only through a continual process of making equal: making those of greater potential but unequal ability equals in resources and opportunities, so they may, through the use of those resources, be cultivated into eventual equals, as well as making former equals of declining potential into unequals.

Further, because progressive elitism is a system of sorting individuals according to absolute potential as well as present ability, it requires two added conditions that are incompatible with the strong classism and radical inequality of Nietzsche's conservative elitism. The first requirement is a system of graduated classes, of varying levels of elite status rather than a single elite class, a system that implies a generous vertical distribution of resources among levels or classes. The second requirement is a generous horizontal distribution of resources across many areas of human ability and accomplishment. Both requirements are incompatible with radically unequal distribution to the top, and both follow from a simple problem: in a system of conservative elitism, where will the future members of the elite come from, and how will we efficiently discover and cultivate them?

The first condition, a graduated hierarchy, is necessary to identify and promote potential as well as actual levels of ability. Because talent is identified only through training and testing (an allocation of resources and opportunities to individuals of as yet unproven ability), individuals of greater potential cannot be cultivated unless there are lower points of entry into the elite: graduated levels of elite status serving as transitions to higher levels. But such a system typical of meritocratic social institutions such as educational and professional systems of qualification and rank - makes impossible a single, stable, and welldefined elite class. Indeed, although in practice meritocratic institutions often do preserve a stable elite, they do so precisely to the degree that they fail to be progressive. Insofar as they are progressive, they paradoxically approximate an elitism without an elite: a complex, changing, permeable hierarchy of differing levels of accomplishment, privilege, and opportunity, with no stable membership at any level. 
The second condition, a wide distribution of resources in many areas of human ability, is necessary because progressive elitism aims at human excellence absolutely, not in any particular ability. Just as individuals may possess greater potential ability than those with greater actual ability, certain abilities or forms of human achievement may, at any given time, have greater potential for development than others. Consequently, progressive elitism must invest resources not only at all class levels, but in diverse areas of human achievement. Once again, the principle concern is the future rather than current elite. Promoting the most accomplished current members of the elite in an activity that has little room for progress is less efficient that promoting individuals of lesser ability in an activity with a substantially higher potential for absolute development.

Consequently, progressive elitism not only cannot preserve a true elite class, it also cannot sustain radical inequality. To the degree that it is efficient in practice, it will, paradoxically, be egalitarian: a graduated hierarchy of distribution that - if it is to ensure sufficient horizontal distribution across class levels and areas of achievement - cannot function with radical resource gaps between the highest and lowest levels.

\section{The Case for Efficient Egalitarian Enhancement: Power as Increase}

We are left with a choice between egalitarianism and a progressive hybrid of weak elitism and egalitarianism that bears little resemblance to Nietzsche's nostalgic picture of classical aristocracies. But even this weakened version of elitism fails to provide a more efficient means of human enhancement. For progressive elitism aims at the greatest absolute quantity of power or feeling of power.

Nietzsche's view, in contrast, prioritizes increase over level. Recall that he defines the good in The Antichrist as 'the feeling that power increases' (A 2) and in Beyond Good and Evil identifies human enhancement as 'the development of ever higher, rarer, more remote, further-stretching, more comprehensive states' (BGE 257). The emphasis in such passages is not on level but on ever higher development, the length of the 'stretch' between past and present states. Consequently, goodness is not the quantity but the increase of power, not the intensity of feeling but the act of intensification. And so enhancement does not track absolute quantity of power or intensity. On the contrary, it tracks changes in quantity and intensity, and egalitarianism best promotes positive, continual changes in both the quantity and intensity of power.

Consider the case of two competitive runners. The first runner is a professional champion whose level of ability is 9 out of a maximum possible level of 
10, while the second runner is a novice who scores 1 on the same scale. Progressive elitism must prioritize the first runner in the allocation of resources and opportunities, since the first runner is far more likely to attain the highest absolute level of ability.

However, the first runner can only increase her ability by one point, while the second runner can potentially increase her ability by nine points. If the measure of the human good is the increase of power and the feeling of power, the champion runner has a surprisingly small share: she cannot increase her power by a significant amount; she will not be able to continually increase it; and, given the modest degree of increase, she is unlikely to experience a significant change in the intensity of her feeling of power. The novice runner, in contrast, can increase her power and intensify her feeling of power many times over. Consequently, on Nietzsche's conception of the good and happiness as the increase of power and feeling of power, she is potentially the greater individual.

What is most surprising about the prioritization of increase over absolute quantity is that it is precisely the most powerful and able who have the least share in the good, precisely because the potential for improvement declines with increased ability. Yet this counterintuitive outcome is perfectly consistent with Nietzsche's own depiction of an ideal agonistic society. Recall that in 'Homer's Contest,' Nietzsche admires the Ephesians for removing contestants whose abilities are too superior. Once again - despite his professed prohibition against 'making equal' - Nietzsche's conception of power undermines his aristocratic nostalgia.

The ancient strategy of ostracism is not merely a matter of saving the contest by ensuring equality among competitors. The practice also reduces the overall level of achievement in order to make room for continued, and greater, increases in achievement. It is an act of leveling (another Nietzschean taboo) that levels in order to enable elevating and equalizes in order to make room for new inequalities, suggesting that the true good of the contest is found in the activities of resistance and overcoming as such, not in the state of ability or power achieved through them. ${ }^{42}$ Nietzschean enhancement promotes the activity of enhancing and the feeling of enhancement for their own sake, and not as a means toward any intrinsically valuable level of ability or degree of feeling.

Consequently, egalitarianism is a more efficient means of Nietzschean enhancement than any form of elitism. First, by promoting equality of powers,

42 Compare Suits' distinction of the 'prelusory' and 'lusory' goals of games in The Grasshopper, pp. 50-51. 
it establishes conditions that promote competitive resistance, which, in turn, promotes the will to power, the feeling of power, and the increase of both quantitative and qualitative power. In contrast, conservative elitism protects an elite from competitive resistance, thereby undermining power.

Second, by distributing resources widely at all levels and in all areas of human achievement, egalitarianism actively prevents the consolidation of power in the form of conservative elitism, in contrast to progressive elitism, which succeeds only insofar as it approximates egalitarianism, otherwise devolving into conservative elitism.

Finally, by promoting human enhancement at all levels and in diverse areas of human ability through broad resource distribution, egalitarianism establishes conditions that better promote the continual increase of power and the feeling of power, in contrast to elitism, which promotes superior levels of ability at the expense of their continued increase. 